\title{
Physical properties of soil in the early stage of an agroforestry system in the High Andean zone
}

\author{
Propiedades físicas del suelo en la etapa de establecimiento de un \\ sistema agroforestal en la zona Alto Andina
}

\author{
M-Alonso Muñoz-Rodríguez; Iván A. Delgado-Vargas²; Jennyfer Cristina Guerrero J.; \\ Anyi Valeria Andrade $B^{4}$.
}

\begin{abstract}
ARTICLE DATA
Research professor, M.Sc. Universidad de Nariño, Pasto, Colombia, martinmunoz236@ udenar.edu.co.

2 Research professor, M.Sc. Universidad de Nariño, Pasto, Colombia, ivan.delgado@ udenar.edu.co.

3 Agroforestry Engineer, Universidad de Nariño, Pasto, Colombia, jennyferguerrero08@udenar.edu.co.

4 Agroforestry Engineer, Universidad de Nariño, Pasto, Colombia, anyiandrade951@udenar.edu.co.
\end{abstract}

Cite: Muñoz-Rodríguez, M.; Delgado-Vargas, I.; Guerrero, J.; Andrade, A. (2020). Physical properties of soil in the stage of establishment an agroforestry system in the High Andean zone. Revista de Ciencias Agrícolas. 37(1): 70-79.

doi: https://doi.org/10.22267/rcia.203701.128

Received: September 092019.

Accepted: March 232020.

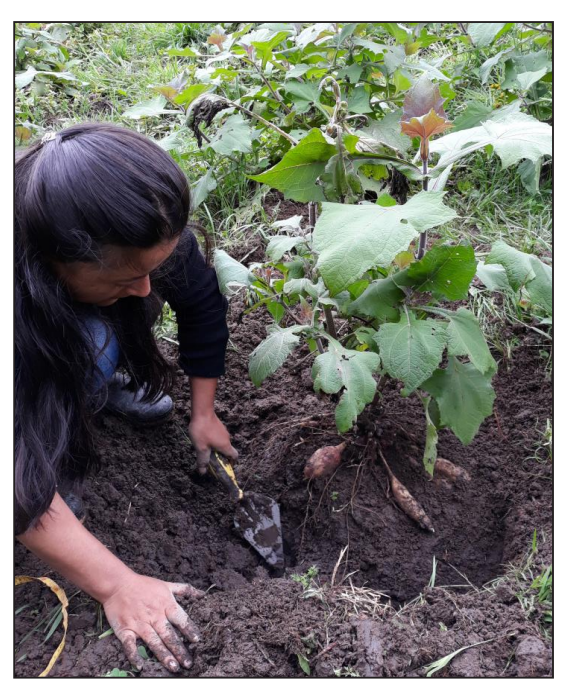

\section{ABSTRACT}

In Nariño, Colombia, land use has generated some problems such as erosion, compaction, lack of fertility, among others, so it is necessary to search for alternatives to mitigate these impacts. The objective of this study was to evaluate some physical properties of the soil in an agroforest system with Morella pubescens (Humb. \& Bonpl. ex Willd.) Wilbur with Smallanthus sonchifolius (Poepp.) H.Rob, in the experimental farm of Botana, in the city of Pasto, Nariño, where the bulk density, real density, total porosity, structural stability properties and distribution of aggregates were analyzed. The datas were obtained in two phases: $\mathrm{f} 1$ and $\mathrm{f} 2$ before and after agroforestry system implementation, respectively. A randomized complete block design with three treatments and three replications were used. The treatments corresponded to plant densities, T1: $S$ sonchifoliuos, sowed to $1 \times 1 \mathrm{~m}, \mathrm{~T} 2: 0.8 \times 0.8 \mathrm{~m}$ y T3:0.5x0.5m, with three replications. $M$ pusescens was stablished to $4 \times 4 \mathrm{~m}$ between plants and $9 \mathrm{~m}$ between rows and the control (f1). The statistics have differences between f1 (control) and f2 (treatments), to the structural stability properties and distribution of aggregates. The ground suffered a structural stability change to stable lightly (0.97 D.P.M) in f1 to a stable moderate (2.53 D.P.M), in f2. The distribution of aggregates passed to $60 \%$ in $\mathrm{f} 1$ to $70.3 \%$ in $\mathrm{f} 2$, with a media aggregation status. The different agroforest systems management could help, in the long term, by improving the structure of the ground through the vegetal material of arboreal component, the application of a minimum farming and the addition of organic matter.

Key words: apparent density; aggregate distribution; structural stability; Morella pubescens; Smallanthus sonchifolius.

\section{RESUMEN}

En Nariño, Colombia, el cambio de uso del suelo ha generado problemas de erosión, compactación, pérdida de la capa fértil del suelo, entre otros, siendo necesario buscar alternativas que minimicen estos impactos. El estudio se realizó con el objetivo de evaluar algunas de las propiedades 
físicas del suelo en un sistema agroforestal con Morella pubescens (Humb. \& Bonpl. ex Willd.) Wilbur, en asocio con Smallanthus sonchifolius Poepp.) H.Rob, en la Granja Experimental Botana, municipio de Pasto, donde se analizó la densidad aparente, densidad real, porosidad total, distribución de agregados y estabilidad estructural del suelo. Los datos se obtuvieron en dos fases; fase 1 (f1) y fase 2 (f2) antes y después de la implementación del sistema agroforestal, respectivamente. Se utilizó un diseño de bloques completos al azar con tres tratamientos y tres repeticiones. Los tratamientos correspondieron a densidades de siembra T1: S. sonchifolius sembrado a $1 \mathrm{x} 1 \mathrm{~m}, \mathrm{~T} 2: 0.8 \mathrm{x} 0.8 \mathrm{~m}$ y T3:0.5x0.5m. M. pubescens fue establecido a 4 x $4 \mathrm{~m}$ entre plántulas y a 9m entre líneas de M. pubescens y el testigo. Se presentaron diferencias estadísticas significativas entre f1 (testigo) y f2 (tratamientos), para las propiedades estabilidad estructural y distribución de agregados. El suelo sufrió un cambio en la estabilidad estructural pasando de ligeramente estable (0.97 D.P.M) en f1 a moderadamente estable (2.53 D.P.M), en f2. La distribución de agregados pasó de un $60 \%$ en $\mathrm{f} 1$ a un $70.3 \%$ en la f2. El manejo de sistemas agroforestales puede contribuir a mediano y largo plazo en la mejora de la estructura del suelo mediante la incorporación del material vegetal del componente arbóreo, la aplicación de una labranza mínima y la adición de materia orgánica.

Palabras clave: Densidad aparente; distribución de agregados; estabilidad estructural; Morella pubescens; Smallanthus sonchifolius.

\section{INTRODUCTION}

The ground component, is one of the most important and determinant resources in the agricultural activities. It is the base for the development in the communities; therefore, it provides and disposes food and resources to their use. In the department of Nariño, during the last years, its areas dedicate to these kind of activities, has found degradation and decreases in their productive capacity (approx. 2000 hc/ year). It has seen in the lower productive capacity to the harvest, Ambiental conflicts and erosive processes due to the inadequate management to the resource and the low technological in the territory (Burbano, 2016).

Nariño's ground have been affected by the implementation and management of monocultures by asking more quantity of agrochemist, taking into account this problematic the attention has been focused in the searching of alternatives in the sustainable production, to reduce some impacts such as the evidence in the application of agroforestal science that promote to the improve and maintenance to the grounds characteristics, however the knowledge to these dynamics and interactions to the high andean region, it is low and had not allowed to generate some strategies according to the needs and local terms, so a low level to acceptability and acceptance. (Alvarado et al., 2011; Urbano et al., 2019).

In this way, the combination of trees with crops between their stripes or alleys is constituted as a practice of great potential where the perennial woody multipurpose being nitrogen fixators, allow to incorporate this element naturally into the soil and crops (Morales, 2018; Cherubin et al., 2019). The wax laurel (Morella pusbecens (Humb. \& Bonpl.) ex Willd.) Wilbur), a tree species, with a high adaptability in the area, tolerance to external factors, which presents at its roots the actinomycete of the genus Frankia, responsible for the capture of nitrogen (Molina et al., 2000). In associate with the yacon species (Smallanthus sonchifolius (Poepp.) H.Rob), presents great regrowth capacity, low demand in agronomic management and fertilizers, resistant to competition with invasive weeds (Nieto et al., 2004). 
Rojas and Parra (2018) mentioned the importance of the implementation of native trees, through their goods and services contribute to the farmer and his family, serve as windbreaker barriers to crops such as $S$. sonchifolius, which has a fragile stem and is susceptible to overturning. The search for alternatives of primary and secondary transformation of this valuable species, of plant genetic resources, and that in the future can be part of a process of agro-industrial productive conversion for agroecosystems of high Andean mountain.

Sáenz (2019) argues that in the Latin American context, there is a promising future for Andean highland plants such as $S$. sonchifolius, with immediate and medium-term possibilities for commercialization in several markets. Being a viable economic alternative for producers, incorporating it into its production systems, however, the country does not have a large-scale production of this tuber, and its low knowledge in the market has been a consequence of the poor research and development of it (Calderón et al., 2017).

According to the above, it is important to study the physical properties of the soil, because they largely determine the capacity of many of the uses that man makes; to understand the extent to which and how they influence plant growth (Morales, 2018).

Therefore, the present research evaluated some physical soil properties such as apparent density, actual density, total porosity, aggregate distribution and structural stability in an agroforestry system of $M$. pubescens in associated with $S$. sonchifolius, in the Experimental Botana Farm, before the establishment and at the end of a production cycle of $S$. sonchifolius, according to the established planting distances.

\section{METHODS AND MATERIALS}

Localization. This research was done in the experimental of the University of Nariño, located in the path Botana, municipality of Pasto, the study site locates at coordinates $77^{\circ}$ $18^{\prime} 58^{\prime \prime} 0$ y $1^{\circ} 10^{\prime} 11.4^{\prime \prime} \mathrm{N}$, at $2820 \mathrm{msnm}$ of altitude, average temperature of $12{ }^{\circ} \mathrm{C}$, annual rainfall of 800 to $1000 \mathrm{~mm}$, relative humidity 70 to $80 \%$ with 900 hours sun approximately (IDEAM, 2010). According to IGAC (2004), it belongs to the life zone, low wet forest montano (hb- BM); according to the taxonomic group, this soil is classified as Acrudoxic Fulvudands with a rolling topography.

A minimum farm work was done to a natural cropped, to the component agricultural sowing and to the forest tree component harvest it was used to dig to holes in the experimental plot two samples, the first one in phase 1 (F1: before the crops implementation) and the second one in phase 2 (F2: harvest to $S$. sanchifolius) the results were implemented in the physics lab of soils of the University of Nariño. Where an evaluation about certain physical properties such as bulk density (Ba), real density (Dr) total porosity (p), structural stability (EE), and aggregates distribution (GAD).

Experimental Design. To evaluate the effects in distances of harvest of $S$. sanchifolius, a silviculture system was established, using a complete block using a design with three treatments and three repetitions. (3x3). The treatments corresponded to the density to the crops, the first treatment (T1) S. sonchifolius the first treatment, was cropped to 1 meter between plants, treatment two (T2) S. sonchifolius $0.80 \mathrm{~m}$ between plants, and the treatment 3 (T3) $S$. sonchifolius cropped to $0.50 \mathrm{~m}$ between plants 
and the absolute control (a lot without any ban) the forest tree component was established two months before the crops of $S$. sanchifolius $4 \times 4$ between sledding and 9 meters between lines.

Materials. The plants of $S$. sanchifolius was acquired for articulated productors to the "Red de Guardianes de las Semillas" in the department of Nariño. The seedlings of $M$. pubesncses were acquired in some nurse rings to the zone, with an initial high average of $15 \mathrm{~cm}$.

Soil sampling. According to the Chaves and Delgado methodology (2015), for physical soil analysis, random zigzag sites were located in the sampling area, where the organic surface layer of the soil was removed. With the help of a shovel, the six subsamples were extracted for each treatment at $20 \mathrm{~cm}$ each, homogenized in a plastic container free of impurities and then a representative sample of $1 \mathrm{~kg}$ was taken which was placed in a plastic bag with airtight closure and subsequently the samples were labeled for each treatment (Table 1).
Statistics Analysis. A t-test was performed to make comparisons between f1 (before crop planting) and f2 (S. sonchifolius harvest). To assess the statistical differences between treatments in $\mathrm{f} 2$, a variance analysis and Tukey test were performed to separate the averages from the treatments. Statistical analyses were carried out with the Infostat Statistical Package program (Di Rienzo et al., 2010) and the Excel program.

\section{DISCUSSION AND RESULTS}

Bulk density, actual density and total porosity before and after the establishment of the farming arrangement in alleys of $M$. pubescens and $S$. sonchifolius. The results of the test (Table 2) indicated that there were no significant statistical differences for the variables Apparent Density (Da), Actual Density (Dr) and Total Porosity $(\% \mathrm{P})$ between the witness (F1: prior to the establishment of the agroforestry system) and treatments (f2: Sowing distances of $S$. sonchifolius).

Table 1. The Methodology used for the assessment of physical properties.

\begin{tabular}{lll}
\hline \multicolumn{1}{c}{ Parameter } & \multicolumn{1}{c}{ Method } & \multicolumn{1}{c}{ References } \\
\hline Texture & Bouyoucos & Bouyoucos (1936) \\
Real density $\left(\mathrm{g} / \mathrm{cm}^{3}\right)$. & Picnometer & Unigarro and Carreño (2005) \\
Bulk density $\left(\mathrm{g} / \mathrm{cm}^{3}\right)$. & Cylinder Volume & IGAC (1990) \\
Total porosity & Calculated by Da y Dr* & IGAC (1990) \\
Distribution of aggregate size (dry) & Shacker & IGAC (2006) \\
Structural stability (húmid) & Yoder Method & Yoder (1936) \\
\hline
\end{tabular}

*Da: bulk density, Dr: real density 
Table 2. Results of the t-test for some physical properties of the arrangement grown in alleys of M. pubescens and S. sonchifolius, in Botswana, municipality of Pasto.

\begin{tabular}{lccccc}
\hline Variable & Phase I & Phse II & T calculated & T tabulated & E.D \\
\hline Da & $0.92^{\mathrm{a}}$ & $0.99^{\mathrm{a}}$ & 1.21 & 4.30 & \\
Dr & $2.36^{\mathrm{a}}$ & $2.44^{\mathrm{a}}$ & 0.91 & 3.18 & \\
\%P. & $60.41^{\mathrm{a}}$ & $59.09 \mathrm{a}$ & 0.43 & 4.30 & \\
E.E & $0.97^{\mathrm{a}}$ & $2.52 \mathrm{~b}$ & 29.41 & 4.30 & 0.85 \\
DAG & $3.05^{\mathrm{a}}$ & $3.9 \mathrm{~b}$ & 3.42 & 3.18 & 0.54 \\
\hline
\end{tabular}

E.D: estándar desviation

Equal letters meaning that there were not significant differences

These results are consistent with those found by Gaviria and Herrera (2013), in the study of the physical properties of the soil in an agroforestry arrangement laurel wax $(M$. pubescens), established at $4 \times 4 \mathrm{~m}$, with chocho (Lupinus mutabilis) in the municipality of Pasto, in three different agroforestry arrangements; (fix 1: M. pubescens, fix 2: M. pubescens $\mathrm{x}$ L. mutabilis $0.15 \times 0.20 \mathrm{~m}$ and arrangement 3: M. pubescens $\mathrm{x}$ L. mutabilis $0.30 \times 0.60 \mathrm{~m}$ ); in which they did not show significant differences for the same variables evaluated.

Ramírez and Vélez (2002), Zuñiga et al. (2011) mention that the physical properties of the soil are not affected, because the changes depend to a large extent on the origin of the soil, its evolution and the contents of organic matter, waiting for changes in these properties in a longer evaluation period than that contemplated in this research, since the actual and apparent density and total porosity, are very stable soil properties, which in a short period of time of use are not modified.

Similarly, Novillo et al. (2017) evaluated five land use systems, analyzed the variables $\mathrm{Dr}$ and $\% \mathrm{P}$, which did not present significant statistical differences between coverages and soil depth, also, apparent density tends to increase depending on the type of use, so it can be inferred that the properties change according to soil use (Morales, 2018).

However, total porosity showed some tendency to decline (60.41 to 59.09\%), although the data were not significant, related to the slight increase in $\mathrm{Da}$ between $\mathrm{f} 1$ and $\mathrm{f} 2\left(0.92\right.$ to $\left.0.99 \mathrm{Mg} \mathrm{m}^{-3}\right)$. Nariño soils are characterized by densities less than $1 \mathrm{Mg}$ $\mathrm{m}^{-3}$ (IGAC, 1986). The Da over a long period of time (45 years) increases with the type of land use and depth, reorganizing the removed particles and occupying the space corresponding to water and air; which differs from the soils of the Botana farm, with a tendency to compact, which affects the moisture retention capacity and limits the root development of the plants (Volverás et al., 2016).

Moreover, Leyva et al. (2018), report lower values of apparent soil density in agroforestry systems with respect to grasslands, stating that the tree component improves this property, confirming that land use, vegetation and soil type are factors that are interrelated and determine the physical and chemical properties of soils (Gaspar and Navas, 2013).

Structural stability before and after to the establishment to the alley cropping. The obtained results showed that the soil suffered a 
change in the structural stability, the higher in F II with 2.52 W.M.D. in relation with F1 with 0.97 W.P.D. (Figure 1).

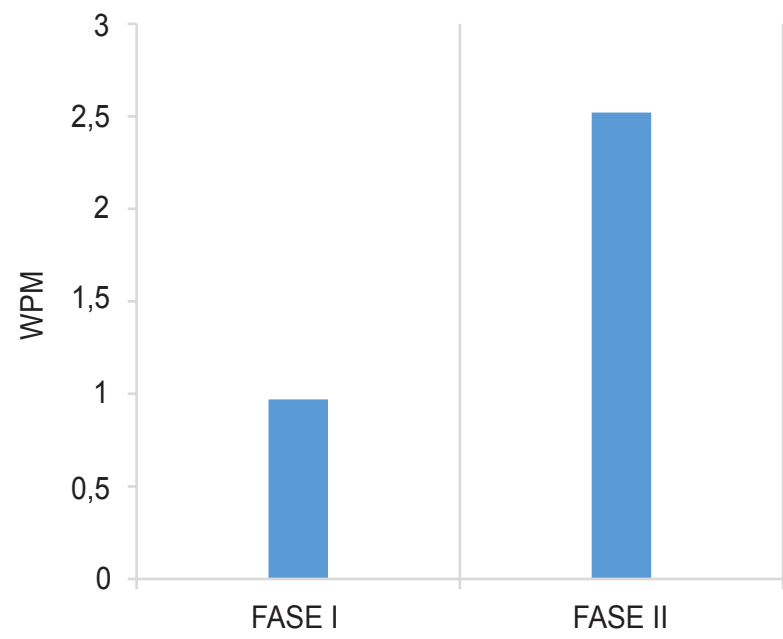

Figure 1. Structural stability before and after to the establishment in the alley cropping.

According to the classification IGAC (2006) (Table 3), the structural stability of the soil in this study ranges from slightly stable to moderately stable. This is due to the resistance to deterioration and erosion offered by the intensity, type of use and handling of soil machining (Buenaver and Rodríguez, 2016).

Table 3. Classification diameter medial weighted.

\begin{tabular}{cc}
\hline WMD (mm) & Structural stability \\
\hline$<0,5$ & Unstable \\
$0.5-1.5$ & slightly stable \\
$1.5-3.0$ & moderately stable \\
$3.0-5.0$ & Stable \\
$>5.0$ & Very stable \\
\hline
\end{tabular}

Source: IGAC (2006).

For this research the use of plant material of $S$. sonchifolius was decisive in the arrangement of the solid phase of the soil, since the distribution of its aggregates and porous space makes possible the preservation of this property; likewise, organic matter and the coverage provided, decreased the agroclimatic impact on the system, avoiding the structural damage of the soil by direct radiation from the sun and the effect of rain on an uncovered soil (Lal and Shukla, 2004; Molina and Moreno, 2017).

These results are consistent with Gaviria and Herrera(2013),whofound significantdifferences for wet aggregates, in an agroforestry system of M. pubescens associated with L. mutabilis in the municipality of Pasto, which shows that there is greater protection of the soil against raindrops. A minimum state of aggregation is presented in plots at full exposure, with minimal tillage and crop rotation, by possessing finer aggregates that absorb more energy from raindrops, while thicker aggregates offer greater resistance to separability. Decreasing the values of apparent density and resistance to penetration after soil machining (Méndez et al., 2016).

Distribution of aggregates (granulometry) before and after the establishment of the farming arrangement in alleys of $M$. pubescens and $S$. sonchifolius. The t-test found significant statistical differences between $\mathrm{f} 1$, with $60 \%$ of aggregates $(>0.5 \mathrm{~mm})$ and f2 with $70.3 \%$ aggregates $(>0.5 \mathrm{~mm})$, according to the rating IGAC (2006), the data obtained correspond to an average aggregation state, as shown in Table 4. 
Table 4. Clasification of the agregation state.

\begin{tabular}{ccc}
\hline Aggregated percentage $>\mathbf{0 . 5}$ & Aggregation state (ea) & kind \\
\hline$>90$ & Too high & 1 \\
$90-80$ & High & 2 \\
$80-35$ & Media & 3 \\
$35-25$ & Low & 4 \\
$<25$ & Too low & 5 \\
\hline
\end{tabular}

Source: IGAC (2006).

Whalen and Chang (2002), claim the increase in soil organic matter is the cause of the higher proportion of the soil being concentrated in macroaggregates; promoting soil stability and aggregation; Likewise, Martínez et al. (2008) and Gaviria and Herrera (2013) refer to average size aggregates $<0.5 \mathrm{~mm}$, which can block thicker pores, making it difficult to penetrate air into the ground; this is also due to the organic carbon of the soil, which has a positive correlation with the size of the aggregates.

The distribution of aggregates in $\mathrm{f}$ II was higher (Figure 2), which may have been improved by the penetration of the roots of $S$. sonchifolius; although the system has been in place for a very short time, it can be inferred that the successive decomposition of microbial biomass, possibly attracted by the exuded produced by the agricultural component, improves the distribution of soil aggregates, confirming what is reported by Zuñiga et al. (2011) and Volverás et al. (2016) who claim that increasing the proportion of macro over microplates increases soil quality.

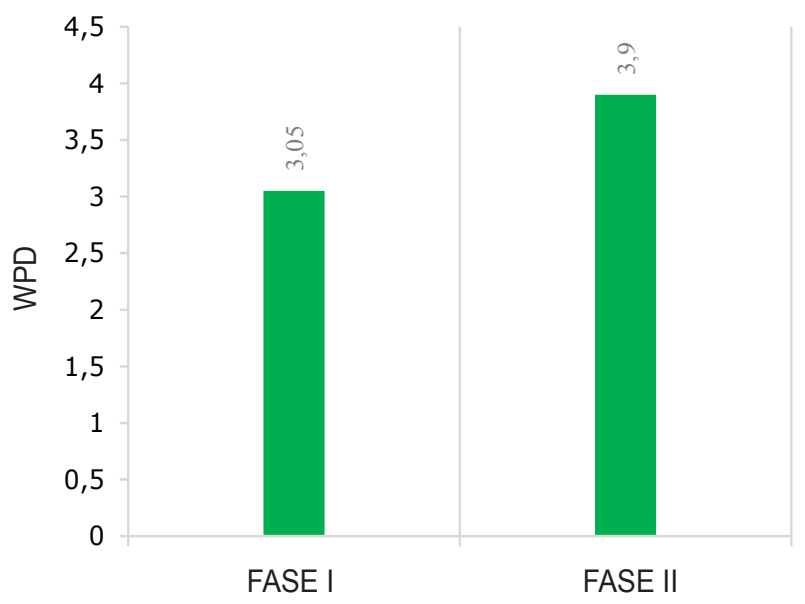

Figure 2. Distribution to the aggregated DAG (gronunoletre) before and after to the establishment from alley crops.

Physical comparation to the soil between the treatments to the phase II using soil in alley crops. According to the analysis to variance (Table 5), there is not any significant statistical differences between treatments. 
Table 5. Analysis of variance of some physical properties of soil between $\mathrm{f} 2$ treatments of the agroforestry system.

\begin{tabular}{lcccccc}
\hline \multirow{2}{*}{\multicolumn{1}{c}{ F.V }} & G.L & \multicolumn{5}{c}{ C.M } \\
\cline { 3 - 7 } & & Da & Dr & \%P & E.E & DAG \\
\hline Model & 4 & 6.8 E-04 & 0.01 & 0.21 & 0.01 & 0.59 \\
Block & 2 & 9.3 E-04 & 0.01 & 0.41 & 5.8 E-04 & 0.41 \\
Treatment & 2 & 4.3 E-04 & 1.4 E-03 & 0.001 & 0.02 & 0.46 \\
Error & 4 & 6.7 E-05 & 0.01 & 3.07 & 0.07 & 0.29 \\
Total & 8 & & & & & \\
\hline
\end{tabular}

F.V: Source of variation; G.L: Degrees of freedom; C.M: Mean square. ${ }^{* *}=$ highly significant differences.

This is consistent with the information reported by Ramírez and Vélez (2002), in the evaluation of an agroforestry arrangement of M. pubescens with Solanum tuberosum L. and Allium sativum L., a tendency was found to improve the physical properties of the soil over time; by the effect of the roots can improve the aggregation of the soil in the long term, by effects of root penetration, modification of the water regime, production of exudates, entanglement of aggregates caused by the roots and decomposition of dead roots (Six et al., 2004; Bronick and Lal, 2005; Molina and Moreno, 2017).

Aggregate distribution and structural stability showed a tendency to improve between f2 treatments. Benavides et al. (2015), found significant differences for three types of use T1 (Kikuyo prairie (Pennisetum clandestinum Hochst. ex Chiov) and grama dulce (Paspalum distichu L.)), T2 (trees dispersed within the pastures, quillotocto (Tecoma stans Griseb.), arrayan (Myrcianthes leucoxyla (Ortega) McVaugh) and pichuelo (Senna pistacifolia (Kunth) H.S. Irwin \& Barneby)) and T3 (the encino forest (Weinmannia tomentosa L. f.), campanillo (Delostoma integrifolium D. Don)) and cucharo (Myrsine guianensis (Aubl.) Kuntze)), for the properties apparent density $(\mathrm{Da})$, actual density (Dr), total porosity (Pt), aggregate distribution (DMP), being able to identify that these properties change according to the different uses of the soil over time.

\section{CONCLUSIONS}

The physical properties of the soil at the stage of establishment of the farming arrangement in alleys M. pubescens with S. sonchifolius, presented minimal differences for the variables: structural stability and distribution of aggregates, which will allow in the long term to improve the structure of the soil by incorporating the plant material of M. pubescens, minimal tillage and the addition of organic matter.

There were no differences in soil properties by the effect of planting distances in phase II (f2), however, the values indicate that these properties tend to improve over time.

\section{ACKNOWLEDGEMENTS}

To the Vice-Rectory of Research and Postgraduate Studies VIPRI of the University of Nariño for the financing of this work. To Gloria Cristina Luna Cabrera, Director of the research group Research Plan and Integral Strengthening of the Communities- PIFIL of the University of Nariño. Jorge Alberto Vélez and William Ballesteros, for the support provided. 
Conflicto de intereses: Los autores declaran que no hay conflicto de intereses.

\section{BIBLIOGRAPHIC REFERENCES}

Alvarado, K.; López, V.; Castillo, J. (2011). Pérdida de suelo por erosión hídrica en diferentes sistemas de producción con papa Solanum tuberosum L. Revista de Ciencias Agrícolas. 28(1): 64-72.

Benavides, E.; Morales, L.; Navia, J. (2015). Propiedades físicas y contenido de materia orgánica en diferentes usos del suelo en Samaniego, Colombia. Revista Agroforestería Neotropical. 5(1): 27-41.

Bouyoucos, G.S. (1936). Directions for making mechanical analysis of soil by hydrometer method. Soil Science. 42(3): 225-228. doi:10.1097/00010694-193609000-00007

Burbano, H. (2016). El suelo y su relación con los servicios ecosistémicos y la seguridad alimentaria. Revista de Ciencias Agrícolas. 33 (2): 117-124. doi: http://dx.doi.org/10.22267/ rcia.163302.58

Buenaver, M.; Rodríguez, E. (2016). Determinación de la estabilidad de agregados del suelo en diferentes agroescosistemas del Departamento de Norte de Santander. Suelos ecuatoriales, Sociedad Colombiana de la Ciencia del Suelo. 46(1 у 2): 42-50.

Bronick, C.; Lal, R. (2005). Soil structure and management: areview. Geoderma. 124 (1 y 2): 3-22. doi: https://doi.org/10.1016/j. geoderma.2004.03.005

Calderón, C.; Fandiño, D.; Chávez, T. (2017). El Yacón: una alternativa para el sector agrícola colombiano. Colombia, Bogotá: Universidad de la Salle. $77 p$.

Chaves, G.; Delgado, J. (2015). Manual de Prácticas de Laboratorio Suelos Generales. Pasto: Editorial Universitaria-Universidad de Nariño. 173p.

Cherubin, M.R.; Chavarro-Bermeo, J.P.; Silva-Olaya, A. M. (2019). Agroforestry systems improve soil physical quality in northwestern Colombian Amazon. Agroforestry Systems. 93(5): 1741-1753.
Di rienzo, J.; Casanoves, F.; Balzarini, M.; González, L.; Tablada, M.; Robledo, C. (2010). Infostat versión. Grupo Infostat. Recovered from http://www. infostat.com.ar

Gaspar, L.; Navas, A. (2013). Vertical and lateral distributions of $137 \mathrm{Cs}$ in cultivated and uncultivated soils on Mediterranean hillslopes. Journal Geoderma. 207-208. doi: https://doi. org/10.1016/j.geoderma.2013.04.034

Gaviria, N.; Herrera, E. (2013). Propiedades físicas del Suelo en el Arreglo Agroforestal Laurel de Cera Morella pubescens H.B.K con Choco Lupinus mutabilis L. en el Municipio de Pasto. Colombia, Pasto: Universidad de Nariño. 28p.

IGAC-Instituto Geográfico Agustín Codazzi. (1986). Estudio general de suelos del Nororiente del Departamento de Nariño. Bogotá: IGAC. 558p.

IGAC- Instituto Geográfico Agustín Codazzi. (1990). Métodos Analíticos de Laboratorio de Suelos. Bogotá: IGAC. 502p.

IGAC - Instituto Geográfico Agustín Codazzi. (2004). Estudio general de los suelos y zonificación de tierras del departamento de Nariño. Colombia, Bogotá: IGAC. 733p.

IGAC-Instituto Geográfico Agustín Codazzi. (2006). Métodos Analíticos de Laboratorios de Suelos. Colombia, Bogotá: Imprenta Nacional de Colombia. 674p.

IDEAM-Instituto de Hidrología y Meteorología y Estudios Ambientales. (2010). Reporte Técnico Estación Meteorológica Botana, Pasto, Nariño: IDEAM. 1p.

Lal, R.; Shukla, M. (2004). Principles of Soil Physics. Marcel Dekker, New York: CRC Press. doi: https:// doi.org/10.1111/j.1365-2389.2005.0756c.x

Leyva, S.; Baldoquin, A.; Reyes, M. (2018). Propiedades de los suelos en diferentes usos agropecuarios, Las Tunas, Cuba. Revista de Ciencias Agrícolas. 35(1): 36-47. doi: http:// dx.doi.org/10.22267/rcia.183501.81

Martínez, E.; Fuentes, J.; Acevedo, E. (2008). Carbono orgánico y propiedades del suelo. Revista de la ciencia del suelo y nutrición vegetal. 8(1): 6896. doi: https://dx.doi.org/10.4067/S071827912008000100006 
Méndez, D.; Becerra, L.; Hernández, H.; Diaz, A.; Muñoz, A. (2016). Incidencia de la mecanización del suelo en el crecimiento vegetativo de papaya (Carica papaya L.). Revista de Ciencias Agrícolas. 33(1): 53-63. doi: http://dx.doi.org/10.22267/ rcia.163301.6

Molina, D.; Moreno, S. (2017). Evaluación de propiedades físico-químicas en diferentes usos y manejos de suelo, región altoandina de Pasto. Pasto: Universidad de Nariño. 36p.

Molina, A.; Narváez, W.; Muñoz, J. (2000). Sistema agroforestal laurel de cera Myrica pubescens H.B.K, intercalado con cultivos transitorios en el municipio de Pasto. Botana. Revista de Ciencias Agrícolas. 17:2. 166-175.

Morales, L. (2018). Utilización de árboles fijadores de nitrógeno Escallonia pendula y Alnus acuminata para la recuperación de suelos erosionados. Colombia: Universidad Nacional Abierta y A distancia - UNAD. 84p.

Nieto, C.; Ramos Veintimilla, R.; Galarza Rosales, J. (2004). Sistemas agroforestales aplicables en la Sierra ecuatoriana. Resultados de una década de experiencias de campo. Ecuador, Quito: Instituto Nacional Autónomo de Investigaciones Agropecuarias - INIAP.195p.

Novillo, I.; Carrillo, M.; Cargua, J.; Moreira, V.; Albán, K.; Morales, F. (2017). Propiedades físicas del suelo en diferentes sistemas agrícolas en la provincia de Los Ríos, Ecuador. Revista Temas Agrarios. 23(2): 177-187.

Ramírez, A.; Vélez, J. (2002). Evaluación preliminar del arreglo agroforestal en líneas de Laurel de cera Myrica pubescens con Papa Solanum tuberosum y Ajo Allium sativum en la vereda Botana. Colombia, San Juan de Pasto: Universidad de Nariño. 17p.

Rojas, W.; Parra, J. (2018). Implementación de un modelo de cultivo de yacón (Smallanthus sonchifolius) para el aprovechamiento medicinal y alimenticio-vereda Julumito, municipio de Popayán, departamento del Cauca. Popayán, Colombia: Universidad Nacional abierta y a Distancia - UNAD. 106p.

Sáenz, S. (2019). Hay mucho que investigar en las raíces y tubérculos andinos. Revista de
Medicina Veterinaria. 38: 7-13. doi: https://doi. org/10.19052/mv.vol1.iss38.1

Six, J.; Bossuyt, S.; Denef, K.; (2004). A history of research on the link between (micro) aggregates, soil biota, and soil organic matter dynamics. Soil \& Tillage Research. 79(1): 7-31. doi: https://doi. org/10.1016/j.still.2004.03.008

Unigarro, A.; Carreño, M. (2005). Métodos químicos y físicos para el análisis de suelos. San Juan de Pasto: Universidad de Nariño. $72 p$

Urbano, M. F.; Pantoja, M. F.; Delgado, I. A.; Cabrera, P. C.; Benavides, I. F. (2019). The effect of green fertilizers on the ecological structure of soil invertebrate communities in an andisol of Southwestern Colombia. Revista de Biología Tropical. 67(6): 1394-1405.

Volverás, B.; Amézquita, E.; Campo, J. (2016). Indicadores de calidad física del suelo de la zona cerealera andina del departamento de Nariño, Colombia. Pasto: Corpoica Ciencia Tecnología Agropecuaria. 17(3):361-377. doi: http://dx.doi. org/10.21930/rcta.vol17_num3_art:513

Whalen, J.; Chang, C. (2002). Macroaggregate Charatacteristics in soils alter 25 annual manure applications. Soil Science Society of America. 66: 1617 - 1647. doi: https://acsess.onlinelibrary. wiley.com/doi/epdf/10.2136/sssaj2002.1637

Yoder, R. (1936). A direct method of agregate analysis of soil and study of physical nature of erosion losses. J. Am Soc. Agron. 28(5): 337-351.

Zuñiga, 0; Osorio, J; Cuero, R; Peña, J. (2011). Evaluación de tecnologías para la recuperación de suelos degradados por Salinidad. Rev.Fac.Nal.Agr. Medellín. 64(1): 5769-5779. 